\title{
Poem: Intra-face
}

\author{
Ericka Johnson
}

\section{Linköping University Post Print}

\section{Tweet}

N.B.: When citing this work, cite the original article.

Original Publication:

Ericka Johnson, Poem: Intra-face, 2015, The European Journal of Women's Studies, (22), 3, 356-357.

http://dx.doi.org/10.1177/1350506815589278

Copyright: SAGE Publications (UK and US)

http://www.uk.sagepub.com/home.nav

Postprint available at: Linköping University Electronic Press

http://urn.kb.se/resolve?urn=urn:nbn:se:liu:diva-126199 
Intra-face

By Ericka Johnson

'Twas three weeks before Christmas

And pretty damn dark

Up north here in Sweden

As I walked through the park.

I was thinking of how

To theoretically base

A medical simulator

And its intra-face;

A tool to teach students

The pelvic exam

With organs and diodes

But no diaphragm.

When doing a study

On how I could teach

I realized the box came

With inserts for each

Type of womb and some ovaries

But even more odd

With a fat pad to mimic

A large woman's bod [y].

Place the thin fat pad

Which came in one piece

Below the abdominal

Skin and - voilà!

You're obese!

It looked like a mouse pad,

Insertable foam

But centimetre thin

And shaped like a dome.

I thought of the women,

Those termed as 'obese'

And thought, it'd take dozens

Of inserts, at least

To model their middles

And properly hide

Their wombs and their ovaries

Deep there inside.'
So I asked the designer

At a factory in Kent

How one little fat pad

Such bulk could represent.

And her answer surprised me.

Quite matter-of-fact,

She explained how the body

Is not so compact.

When fat is kept warm

And enclosed in a space

The cells are real fluid

In movable ways.

And most fat in a woman

Who's been asked to lie

On her back on the table

Slides out of the way.

So the fat pad's a model

Of fat, as it were

When known in the practice

of examining her.

The pad doesn't simulate

Fat on command.

It simulates

Fat as it's felt by the hands.

And nor is the simulator

A model of bones

Of bodies or organs

It simulates 'known'.

To think all this through

I returned to my books

And to feminist science studies

And its various hooks

I applied the term taken

From Karen Barad

'intra-action' - how objects

are not to be had

But rather are compotes

Both the hows and the whats

Of the tools used to know them

And discursive cuts. 
So the body as modelled

Is not its own 'thing',

Ontologically separate

From medicine's zing

Instead, that same body

Can only be known

Through techniques and instruments.

It can't stand alone.

And when it is modelled

What's placed in that wax

Is the practice of knowing it.

Practises, not facts.

So my point with this fat pad

Is merely to say

When talking of simulators

We have to give way

And think of a body

As a knowledge phenomenon

A product of practice

And what it's been done on.

It isn't the fat that

We're trying to model.

It's how the fat's felt.

How it wiggles and wobbles

And how it behaves

During a specific ordeal.

Not what it might be

But how it might feel.

The body, the doctor

Anatomist, wax

Are entangled and "Intra".

Distinctions are hacks.

To think of the model

As representational

Ignores that its agency

Is really relational.

So instead of an interface

Which connotes units,

With representation
Objectified bits

I posit an 'intra-face'

With contours of doing,

Of knowing the body

And contexts ensuing.

And one implication

This insight might give

Is that medical models

Model the body we live

And the way that our doctors

Or anatomy Profs

Can know what our body is

Requires Philosofs.

The term of validity

Ought to be tossed.

And models realistic

Is another one crossed.

At least till we grapple

With accepting the thought

That both of these terms

Without practise are fraught.

A simulator mimics

The way that we know

It's an intra-face for us.

Now let's hope for some snow... 